\title{
Evaluation of Formulations through Testing the Bioefficacy of Selected Trichoderma Isolate against $S$. rolfsii
}

\author{
B. Swathi ${ }^{1 *}$, A. K. Patibanda ${ }^{1}$, J. Krishna Prasadji ${ }^{2}$, \\ P. V. Krishnayya ${ }^{1}$ and M. Lal Ahamed ${ }^{1}$
}

\author{
${ }^{1}$ Agricultural College, Bapatla, 522101, ANGRAU, Guntur, 522034, Andhra Pradesh \\ ${ }^{2}$ Agricultural College, Rajamahendravaram, ANGRAU, Guntur, 522034, Andhra Pradesh
}

*Corresponding author

\section{A B S T R A C T}

\begin{tabular}{|l|}
\hline K e y w o r d s \\
Collar rot, \\
Sclerotium rolfsii, \\
Chickpea, \\
Bioefficacy, \\
Trichoderma, cfu, \\
Talc, Mineral oil
\end{tabular}

The collar rot caused by Sclerotium rolfsii is an important fungal pathogen in chickpea root disease complex causing serious losses. In the present study, efforts were made to prepare and test the bioefficacy of eight solid formulations and three liquid formulations against chickpea collar rot (In vitro and In vivo). The results indicated that, among all the eight solid substrates used, talc powder formulation was found to be the best carrier material to retain and support maximum propagules of Trichoderma compared to the remaining carriers. The mean cfu was highest in talc powder $\left(540 \times 10^{8} \mathrm{cfu} / \mathrm{g}\right)$ followed by pesta granules $\left(450 \times 10^{8} \mathrm{cfu} / \mathrm{g}\right)$; In liquid formulations, mean cfu revealed that mineral oil formulation was found to yield higher $\mathrm{cfu}\left(450 \times 10^{11} \mathrm{cfu} / \mathrm{ml}\right)$. Among the eight solid formulations and three liquid formulations of Trichoderma assessed using soil application and seed treatment methods, talc formulation (51.0\% and $65.9 \%$, respectively), pesta granules (47.7\% and $66.4 \%$ respectively in solid) mineral oil formulation $(50.0 \%$ and $54.0 \%$, respectively in liquid) gave superior disease control against chickpea collar rot.

\section{Introduction}

Chickpea (Cicer arietinum L.) is one of the major pulse crops widely cultivated in tropical, sub-tropical and temperate regions of the world. Among various factors attributed to the low productivity of chickpea, susceptibility to diseases is the most important factor. More than 50 pathogens have been reported to infect chickpea in different parts of the world (Nene et al., 1989). The collar rot caused by Sclerotium rolfsii is an important fungal pathogen in chickpea root disease complex causing serious losses. Among the biotic factors contributing towards low production of chickpea, the collar rot caused by $S$. rolfsii is a major disease reported to cause 55-95\% mortality of chickpea seedlings. Chemical control of the disease is not effective as the soil borne pathogens has a wide host range and survives in soil for a longer period through resting structures. Biological control is proved to be a promising disease management technology against soil borne plant pathogens when applied either alone or 
in combination with other management practices (Papavizas, 1985 and Mukhopadhyay, 1987). Among the successful bioagents, Trichoderma spp. is being extensively used and is available as commercial formulations to manage several soil borne plant pathogens. Trichoderma has compatibility with other management practices in controlling many diseases (Papavizas, 1985).

Trichoderma spp. were the most widely used biocontrol agents since they have antifungal activities (Zaidi and Singh, 2004). Though several species of Trichoderma are found to be effective in managing plant diseases, isolate variation existed in their antagonistic efficacy (Upadhyay and Mukhopadhyay, 1986 and Patibanda et al., 2002). The success of a biocontrol agent depends on its abilityto produce inoculum in excess, grow and proliferate well on the plant parts whenever applied. The population of bioagent in the formulation is an important factor deciding the quantity of product necessary to apply in the field. Failure of antagonist to survive due to shorter shelf life is a major hindrance to consistent field performance. The efficacy can also be increased through strain improvement.

\section{Materials and Methods}

The present investigation was carried out in the Department of Plant Pathology, Agricultural College, Bapatla. The $T$. harzianum isolate, Th4 was used to prepare formulations using different carriers. Solid and liquid formulations of Trichoderma were prepared in the present study to test the viability and bioefficacy of biocontrol agent.

\section{Formulation Development}

Potato dextrose broth (PDB $50 \mathrm{ml}$ ) medium in sterilized $250 \mathrm{ml}$ Erlenmeyer flasks was inoculated with four day old mycelial discs of the isolate $\mathrm{Th} 4$ and incubated at $29 \pm 1{ }^{\circ} \mathrm{C}$ for ten days. The mycelial mat with conidial sporulation was separated from the broth and the mat was macerated using pestle and mortar to make it as biomass. The biomass product was then mixed with the carrier material such as talc powder, farm yard manure (FYM), neem cake powder, vermicompost, gypsum, lignite powder, pesta granules and conidial formulation @ 1:4 ratio (w/w basis) and the mixture was shade dried properly to reduce the moisture content to $8 \%$. The formulations thus prepared were estimated for cfu on TSM. Liquid substrates or carriers such as mineral oil, neem oil and palm oil were used to prepare oil based liquid formulations.

Pesta granules (Connick et al., 1991): Biomass was added to wheat flour and mixed to form cohesive dough by adding required quantity of sterile water. The dough was pressed flat and folded by hand several times. Then one $\mathrm{mm}$ thick sheets (pesta) were prepared and air dried to make them crisp. After drying, dough sheet was ground and passed through an 18 mesh sieve and granules were collected.

Conidial formulation: Conidial formulation was prepared by harvesting conidia in sterile water from PDA plates and the spore mass was centrifuged at $6000 \mathrm{rpm}$ for $15 \mathrm{~min}$. The pellet formed at the bottom of the centrifuge tube was harvested and dried in shade to obtain conidial powder. For delivery, the conidial powder was suspended in sterile water to get the desired concentration $\left(10^{8}\right.$ spores/ml) (Pan and Das, 2009).

Oil based formulation: Oil based formulation was prepared by harvesting conidia in sterile water from PDA plates and mixed with paraffin oil and Tween-20 (surfactant). The spore mass was then centrifuged twice at $6000 \mathrm{rpm}$ for $15 \mathrm{~min}$. The pellet formed at the bottom of the centrifuge tube was suspended in sterile water to form a 
stable emulsion (Ramanujam et al., 2010).

\section{Bioefficacy of Th4 formulation against $S$. rolfsii in vivo}

Twenty day old sorghum grain culture of $S$. rolfsii was inoculated in the top two inches soil of the $6 \mathrm{~kg}$ soil pot @ $6 \mathrm{~g} /$ pot and watered sufficiently. Seed treatment and soil application methodologies were used to evaluate the bioefficacy of biocontrol agent against collar rot of chickpea.

\section{Seed treatment with $\mathbf{T h} 4$ formulation}

Chickpea seeds of cv. Annegiri were coated with dry powder formulation of Th4 just before sowing @ $4 \mathrm{~g}$ of formulation per kg seed (Mukhopadhyay et al., 1992) and each pot was sown with ten chickpea seeds.

\section{Soil application with Th4 formulation}

Two kg Th4 formulation was mixed in $90 \mathrm{~kg}$ FYM and eight $\mathrm{kg}$ neem cake powder and covered for seven days with polythene sheet. The mixture was sprinkled with water intermittently and turned once in every 3-4 days. When the growth of Trichoderma was observed all through the heap, then the mixture $(10 \mathrm{~g} / \mathrm{pot})$ was applied to the pots by mixing in top 2 inches soil.

Seeds were sown in pots @ 10 seeds/pot twenty four hours after pathogen inoculation. Pathogen inoculated and uninoculated pots were maintained stand and disease incidence.

The following formulae were used to assess treatment effects in pot culture.

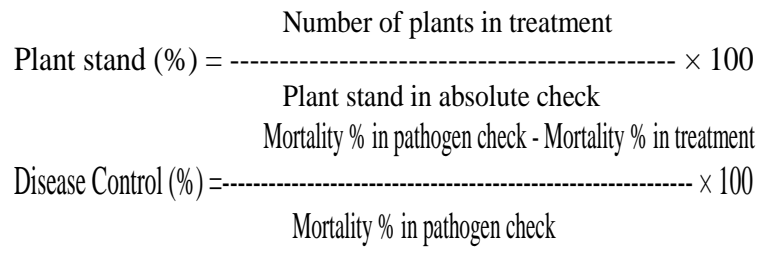

\section{Results and Discussion}

\section{Evaluation of Formulations of Trichoderma in vitro}

The results indicated that, among all the eight solid substrates used, talc powder formulation was found to be the best carrier material to retain and support maximum propagules of Trichoderma compared to the remaining carriers. The mean cfu was highest in talc powder $\left(540 \times 10^{8} \mathrm{cfu} / \mathrm{g}\right)$ followed by pesta granules $\left(450 \times 10^{8} \mathrm{cfu} / \mathrm{g}\right), \quad$ conidial formulation $\left(390 \times 10^{8} \mathrm{cfu} / \mathrm{g}\right), \mathrm{FYM}\left(370 \times 10^{8}\right.$ $\mathrm{cfu} / \mathrm{g})$, neem cake powder $\left(320 \times 10^{8} \mathrm{cfu} / \mathrm{g}\right)$, vermicompost $\left(300 \times 10^{8} \mathrm{cfu} / \mathrm{g}\right)$, lignite $\left(290 \times 10^{8} \mathrm{cfu} / \mathrm{g}\right)$ and gypsum $\left(200 \times 10^{8} \mathrm{cfu} / \mathrm{g}\right)$. On the other hand, in liquid formulations, mean cfu revealed that mineral oil formulation was found to yield higher cfu $\left(450 \times 10^{11} \mathrm{cfu} / \mathrm{ml}\right)$ followed by neem oil $\left(130 \times 10^{11} \mathrm{cfu} / \mathrm{ml}\right)$ and palm oil $\left(100 \times 10^{11}\right.$ $\mathrm{cfu} / \mathrm{ml})$.

In comparison to solid formulations prepared on $\mathrm{w} / \mathrm{w}$ basis, cfu in liquid formulations prepared on $\mathrm{w} / \mathrm{v}$ basis were higher. Further, among solid formulations, talc powder offered better result with maximum $\mathrm{cfu}$ $\left(540 \times 10^{8} \mathrm{cfu} / \mathrm{g}\right)$, while in liquid formulations, mineral oil was found to be the best with $450 \times 10^{11} \mathrm{cfu} / \mathrm{ml}$. Further assessment of different formulations for the bioefficacy against chickpea collar rot was done in pot culture by normalizing the cfu in every formulation to $1-9 \times 10^{8} \mathrm{cfu} / \mathrm{g}$ or $\mathrm{ml}$.

The population density of different formulations is variable and it depends upon nature and type of carrier material used. Deshmukh et al., 1999 reported that the viability of propagules in different formulations may be less because of its low level of nitrogen. FYM was proved to be the most suitable carrier material resulted in high cfu count $\left(7.2 \times 10^{8} \mathrm{cfu} / \mathrm{g}\right)$ followed by talc 
powder having cfu count of $5.3 \times 10^{8} \mathrm{cfu} / \mathrm{g}$ at the time of preparation (Sarode et al., 1998). However, they also reported that neem seed powder has a deleterious effect on Trichoderma, which resulted in gradual decline in population.

Sathiyaseelan et al., (2009) evaluated five different carrier materials viz., paraffin oil + glycerol, paraffin oil + soybean oil, soybean oil + glycerol, paraffin oil and soybean oil for preparation of liquid formulation of $T$. viride and found that $T$. viride in paraffin oil was better than other formulations with $5 \times 10^{9} \mathrm{cfu} / \mathrm{ml}$ at the time of preparation. Similar result was also observed by Al-Taweil et al., (2010).

\section{Bioefficacy of formulations of Trichoderma in vivo using soil application method}

In pathogen inoculated control, germination per cent was $43.3 \%$ and plant stand was only $10 \%$ equivalent to $90 \%$ plant mortality compared to pathogen uninoculated check (100\% germination and $100 \%$ plant stand) (Table 1a).

When per cent plant stand was estimated at 30 DAS, among all the eight formulations applied, talc formulation was proved superior with $56.6 \%$ plant stand though all the remaining formulations such as pesta granules $(53.0 \%)$, neem cake $(46.6 \%)$, vermicompost (43.3\%), gypsum (43.3\%), conidial formulations (43.3\%), FYM (36.7\%) and lignite $(36.6 \%)$ were on par with talc formulation.

Per cent reduction in disease over control was also estimated based on per cent plant stand. Highest per cent disease control was noticed in talc formulation with $51 \%$ and was significantly on a par with pesta granules
(47.7\%), neem cake (40.6\%), conidial formulation $(36.9 \%)$, vermicompost $(36.9 \%)$ and gypsum (36.5\%). The lowest disease control was observed in FYM (29.4\%) and Lignite $(29.1 \%)$ which were significantly lower in comparison with the best formulation i.e., talc powder.

When liquid formulations of Trichoderma such as mineral oil, neem oil and palm oil were assessed for their bioefficacy against $S$. rolfsii, germination per cent in pathogen inoculated control $(36.0 \%)$ was significantly lower compared to all the Trichoderma applied treatments and plant stand was only $12.0 \%$ equivalent to $88 \%$ plant mortality (Table 1b).

When per cent plant stand was observed, the highest plant stand was noticed in mineral oil formulation $(56.0 \%)$ which was significantly on par with neem oil formulation (44.0\%). Palm oil formulation has $36.0 \%$ plant stand which was significantly lower than that in mineral oil formulation but on par with neem oil formulation. Per cent disease reduction over control was estimated and mineral oil formulation $(50.0 \%)$ was significantly higher compared to neem oil $(35.8 \%)$ and palm oil formulations $(26.6 \%)$.

From the above data, it may be interpreted that when Trichoderma formulations were applied in soil, talc powder formulation among solid formulations and mineral oil formulation among liquid formulations were proved better in controlling chickpea collar rot caused by $S$. rolfsii. Several workers reported on bioefficacy of different Trichoderma formulations through soil application to manage disease caused by soil borne plant pathogenic fungi (Jegathambigai et al., 2010; Dubey et al., 2011, Yang et al., 2011 and Mishra et al., 2012). 
Table.1 Bioefficacy of different solid and liquid formulations of Trichoderma Th4 using soil application method against chickpea collar rot

Table.1a Solid formulations

\begin{tabular}{|c|c|c|c|}
\hline S. No. & Treatments & $\begin{array}{c}\text { Plant } \\
\text { stand } \\
(\%)\end{array}$ & $\begin{array}{c}\text { Disease reduction } \\
\text { over control }(\%)\end{array}$ \\
\hline 1 & Talc & $\begin{array}{c}56.6 \\
(48.8)^{\mathrm{b}}\end{array}$ & $51.0(45.6)^{\mathrm{a}}$ \\
\hline 2 & Neem cake & $\begin{array}{c}46.6 \\
(43.1)^{b}\end{array}$ & $40.6(39.6)^{\mathrm{abc}}$ \\
\hline 3 & FYM & $\begin{array}{c}36.7 \\
(37.2)^{b}\end{array}$ & $29.4(32.8)^{\mathrm{bc}}$ \\
\hline 4 & Vermicompost & $\begin{array}{c}43.3 \\
(41.1)^{\mathrm{b}}\end{array}$ & $36.9(37.4)^{\mathrm{abc}}$ \\
\hline 5 & Gypsum & $\begin{array}{c}43.3 \\
(41.1)^{b}\end{array}$ & $36.5(37.0)^{\mathrm{abc}}$ \\
\hline 6 & Lignite & $\begin{array}{c}36.6 \\
(37.2)^{b}\end{array}$ & $29.1(32.4)^{\mathrm{c}}$ \\
\hline 7 & Pesta granules & $\begin{array}{c}53.0 \\
(46.9)^{\mathrm{b}}\end{array}$ & $47.7(43.6)^{\mathrm{ab}}$ \\
\hline 8 & $\begin{array}{l}\text { Conidial } \\
\text { formulation }\end{array}$ & $\begin{array}{c}43.3 \\
(41.1)^{\mathrm{b}}\end{array}$ & $36.9(37.4)^{\mathrm{abc}}$ \\
\hline 9 & $\begin{array}{l}\text { Pathogen } \\
\text { control }\end{array}$ & $10(15.0)^{\mathrm{c}}$ & \\
\hline 10 & $\begin{array}{l}\text { Uninoculated } \\
\text { control }\end{array}$ & $100(90.0)^{\mathrm{a}}$ & \\
\hline \multirow{3}{*}{\multicolumn{2}{|c|}{$\begin{array}{c}\text { SEm } \pm \\
\text { CD }(\mathbf{P}=\mathbf{0 . 0 1}) \\
\text { CV }(\%)\end{array}$}} & 3.0 & 2.7 \\
\hline & & 12.0 & 10.9 \\
\hline & & 11.9 & 12.0 \\
\hline
\end{tabular}

Values in parentheses are arc sine transformed values

Each pot was sown with 10 chickpea seeds of cv. Annegiri

Table.1b Liquid formulations

\begin{tabular}{|c|c|c|c|}
\hline S. No. & Treatment & Plant stand (\%) & $\begin{array}{l}\text { Disease reduction over } \\
\text { control }(\%)\end{array}$ \\
\hline 1 & Mineral oil & $56.0(48.4)^{b}$ & $50.0(48.2)^{\mathrm{a}}$ \\
\hline 2 & Neem oil & $44.0(41.5)^{b c}$ & $35.8(35.3)^{b}$ \\
\hline 3 & Palm oil & $36.0(36.8)^{\mathrm{c}}$ & $26.6(35.3)^{b}$ \\
\hline 4 & $\begin{array}{l}\text { Pathogen } \\
\text { control }\end{array}$ & $12.0(18.0)^{\mathrm{d}}$ & \\
\hline 5 & $\begin{array}{l}\text { Uninoculated } \\
\text { control }\end{array}$ & $100(90.0)^{\mathrm{a}}$ & \\
\hline \multirow{3}{*}{\multicolumn{2}{|c|}{$\begin{array}{c}\text { SEm } \pm \\
\text { CD }(\mathbf{P}=0.01) \\
\text { CV }(\%)\end{array}$}} & 2.4 & 2.4 \\
\hline & & 9.6 & 10.1 \\
\hline & & 11.6 & 14.2 \\
\hline
\end{tabular}


Table.2 Bioefficacy of different solid and liquid formulations of Trichoderma Th4 using seed treatment method against chickpea collar rot

Table.2a Solid formulations

\begin{tabular}{|c|c|c|c|}
\hline S. No. & Treatment & $\begin{array}{c}\text { Plant stand } \\
(\%)\end{array}$ & $\begin{array}{l}\text { Disease reduction } \\
\text { over control }(\%)\end{array}$ \\
\hline 1 & Talc & $70.0(57.0)^{b}$ & $65.9(54.5)^{\mathrm{a}}$ \\
\hline 2 & Neem cake & $43.3(41.1)^{\mathrm{c}}$ & $36.5(37.0)^{\mathrm{a}}$ \\
\hline 3 & FYM & $50.0(45.0)^{b c}$ & $44.0(41.5)^{\mathrm{a}}$ \\
\hline 4 & Vermicompost & $53.0(46.9)^{b c}$ & $47.2(43.2)^{\mathrm{a}}$ \\
\hline 5 & Gypsum & $56.7(48.9)^{b c}$ & $51.4(45.8)^{\mathrm{a}}$ \\
\hline 6 & Lignite & $60.0(50.8)^{b c}$ & $54.8(47.8)^{\mathrm{a}}$ \\
\hline 7 & Pesta granules & $70.0(56.8)^{\mathrm{b}}$ & $66.4(54.6)^{\mathrm{a}}$ \\
\hline 8 & $\begin{array}{l}\text { Conidial } \\
\text { formulation }\end{array}$ & $56.6(48.8)^{b c}$ & $51.5(45.8)^{\mathrm{a}}$ \\
\hline 9 & $\begin{array}{l}\text { Pathogen } \\
\text { control }\end{array}$ & $10(15.0)^{\mathrm{d}}$ & \\
\hline 10 & $\begin{array}{l}\text { Uninoculated } \\
\text { control }\end{array}$ & $100(90.0)^{\mathrm{a}}$ & \\
\hline \multirow{3}{*}{\multicolumn{2}{|c|}{$\begin{array}{c}\text { SEm } \pm \\
\text { CD }(P=0.01) \\
\text { CV }(\%)\end{array}$}} & 3.7 & 4.3 \\
\hline & & 14.6 & 17.6 \\
\hline & & 12.8 & 16.1 \\
\hline
\end{tabular}

Values in parentheses are arc sine transformed values

Each pot was sown with 10 chickpea seeds of cv. Annegiri

Table.2b Liquid formulations

\begin{tabular}{|c|c|c|c|}
\hline S. No. & Treatment & $\begin{array}{c}\text { Plant } \\
\text { stand } \\
(\%)\end{array}$ & $\begin{array}{l}\text { Disease reduction } \\
\text { over control }(\%)\end{array}$ \\
\hline 1 & Mineral oil & $\begin{array}{c}60.0 \\
(50.8)^{\mathrm{b}}\end{array}$ & $54.0(47.3)^{\mathrm{a}}$ \\
\hline 2 & Neem oil & $\begin{array}{c}48.0 \\
(43.8)^{\mathrm{b}}\end{array}$ & $40.3(39.3)^{\mathrm{a}}$ \\
\hline 3 & Palm oil & $\begin{array}{c}50.0 \\
(45.0)^{\mathrm{b}}\end{array}$ & $42.8(40.7)^{\mathrm{a}}$ \\
\hline 4 & $\begin{array}{l}\text { Pathogen } \\
\text { control }\end{array}$ & $\begin{array}{c}12.0 \\
(18.0)^{\mathrm{c}}\end{array}$ & \\
\hline 5 & $\begin{array}{l}\text { Uninoculated } \\
\text { control }\end{array}$ & $\begin{array}{c}100 \\
(90.0)^{\mathrm{a}}\end{array}$ & \\
\hline \multirow{3}{*}{\multicolumn{2}{|c|}{$\begin{array}{c}\text { SEm } \pm \\
\text { CD }(\mathrm{P}=\mathbf{0 . 0 1}) \\
\mathrm{CV}(\%)\end{array}$}} & 2.7 & 3.0 \\
\hline & & 10.5 & 12.5 \\
\hline & & 12.0 & 15.6 \\
\hline
\end{tabular}




\section{Bioefficacy of formulations of Trichodermain vivo using seed treatment method}

In pathogen inoculated control, germination per cent was $43.3 \%$ and plant stand was only $10 \%$ equivalent to $90 \%$ plant mortality (Table $2 a)$.

Plant stand at 30 DAS was highest in talc powder formulation $(70.0 \%)$ and in pesta granules $(70.0 \%)$ which were on par with each other. Least plant stand was recorded with neem cake powder $(43.3 \%)$ which was significantly lower than the best treatment, i.e., talc powder formulation. Seed treatment with lignite (60.0\%), gypsum (56.7\%), conidial formulation (56.6\%), vermicompost (53.3\%) and FYM (50.0\%) were superior to neem cake formulation but inferior to talc powder formulation. Highest per cent disease reduction over control was noticed in pesta granules and talc powder formulation with $66.4 \%$ and $65.9 \%$, respectively.

Further, liquid formulations of Trichoderma such as mineral oil, neem oil and palm oil were used to assess their seed treatment efficacy against $S$. rolfsii. In pathogen inoculated control, germination per cent was $36.0 \%$ and plant stand was only $12.0 \%$ equivalent to $88 \%$ plant mortality (Table $2 b$ ). When data on plant stand data was recorded at 30 DAS the highest plant stand was noticed in mineral oil formulation (60.0\%) which was significantly on par with neem oil and palm oil formulation (48.0\% and 50.0\%).

All the three formulations i.e., mineral oil, neem oil and palm oil formulation were significantly on par among them with 54.0\%, $40.3 \%$ and $42.8 \%$ disease control, respectively. Among all these three, mineral oil formulation was proved better with maximum disease control over others.
Finally from the above seed treatment experiment using solid and liquid formulations, it is clear that talc powder and pesta granule formulation in solid substrates and mineral oil formulation in liquid substrates were proved better in improving germination and disease control in comparison to the other treatments when bioefficacy of formulations were tested in vivo against collar rot pathogen, $S$. rolfsii.

Dubey et al., (2011) and Mishra et al., (2012) used different formulations and carrier material to improve bioefficacy of Trichoderma.

Among different solid formulations tested for the cfu just after preparation and bioefficacy against chickpea collar rot, talc powder formulation proved better with $540 \times 10^{8} \mathrm{cfu} / \mathrm{g}$ of formulation and $65.9 \%$ and $51.0 \%$ disease control when applied through seed and soil application methods, respectively. Among different liquid formulations tested for the $\mathrm{cfu}$ just after preparation and bioefficacy against chickpea collar rot, mineral oil formulation proved better with $450 \times 10^{11} \mathrm{cfu} / \mathrm{ml}$ of formulation and $54.0 \%$ and $50.0 \%$ disease control when applied through seed treatment and soil application methods, respectively.

Based on the results obtained in the present investigation, seed treatment method appeared to offer better disease control compared to soil application as talc powder seed treatment $(65.9 \%)$ out yielded talc powder as soil application $(51.0 \%)$ and mineral oil seed treatment $(54.0 \%)$ out yielded mineral oil as soil application $(50.0 \%)$ in terms of disease control. Trichoderma when applied as seed treatment grows readily and multiplies along with the developing root system by improving the biological soil suppressiveness. The effectiveness of Trichoderma as seed treatments is probably determined not only by their biocontrol qualities but also by their 
abilities to multiply in the rhizosphere when applied to seed.

\section{References}

Al-Taweil, H.I., Osman, M.B., Abdulhamid, A., Norhayati, $M$ and Wan Yussof, W.M. 2010. Comparison of different delivery system of Trichoderma and Bacillus as biofertilizer. Advances in Environmental Biology. 4 (1): 31-33.

Connick, W.J., Boyette, C.D and McAlpine, J.R. 1991. Formulations of mycoherbicides using a pasta like process. Biological Control. 1: 281287.

Deshmukh, A., Matte, B.D and Bhaisre, B. 1999. Flyash as a source of plant nutrients and soil conditioner. Journal of Soil and Crops. 9: 278-279.

Dubey, S.C., Tripathi, A., Bhavani, R and Singh, B. 2011. Evaluation of seed dressing and soil application formulations of Trichoderma species for integrated management of dry root rot of chickpea. Biocontrol Science and Technology. 21 (1): 93-100.

Jegathambigai, V., Wilson, R.S and Wijesundera, R.L.C. 2010. Effect of Trichoderma spp. on Sclerotium rolfsii, the causative agent of collar rot on Zamioculcas zamiifolia and an on farm method to mass produce Trichoderma species. Plant Pathology Journal.1: 19.

Mishra, D.S., Prajapati, C.R., Gupta, A.K and Sharma, S.D. 2012. Relative bioefficacy and shelf life of mycelial fragments, conidia and chlamydospores of Trichoderma harzianum. Vegetos. 25 (1): 225-232.

Mukhopadhyay, A.N. 1987. Biological control of soil borne plant pathogens by Trichoderma spp. Indian Journal of Mycology and Plant Pathology.17: 110.
Mukhopadhyay, A.N., Shrestha, S.M and Mukherjee, P.K. 1992. Biological seed treatment for the control of soil borne plant pathogens. FAO Plant Protection Bulletin. 40: 21-30.

Nene, Y.L., Sheila, K., Sharma, S.B., 1989. A world list of chickpea (Cicer arietinum L.) and pigeonpea (Cajanus cajan) pathogens. Legume pathology progress report-7. Patancheru, ICRISAT: 23.

Pan, S and Das, A. 2009. Combining organic substrates for formulations of Trichoderma harzianum. Journal of Mycology and Plant Pathology.39: 427-431.

Papavizas, G.C. 1985. Trichoderma and Gliocladium: Biology, ecology and potential for biocontrol. Annual Review of Phytopathology.23: 23-54.

Patibanda, A.K., Upadhyay, J.P and Mukhopadhyay, A.N. 2002. Efficacy of Trichoderma harzianum Rifai alone or in combination with fungicides against Sclerotium wilt of groundnut. Journal of Biological Control. 16 (1): 57-63.

Ramanujam, B., Prasad, R.D., Sriram, S and Rangeswaran, R. 2010. Mass production, formulation, quality control and delivery of Trichoderma for plant disease management. The Journal of Plant Protection Sciences. 2 (2): 1-8.

Sarode, S.V., Gupta, V.R and Asalmol, M.N. 1998. Suitability of carriers and shelf life of Trichoderma harzianum. Indian Journal of Plant Protection. 26 (2): 188-189.

Sathiyaseelan, K., Sivasakthivelan, P and Lenin, G. 2009. Evaluation of antagonistic activity and shelf life study of Trichoderma viride. Botany Research International. 2 (3): 195-197.

Upadhyay, J.P and Mukhapadhyay, A.N. 1986. Biological control of Sclerotium rolfsii by Trichoderma harzianum in sugarbeet. Tropical Pest Management. 32: 215-220. 
Yang, X., Lihua, C., Xiaoyu, Y and Qirong Shen. 2011. Formulations can affect rhizosphere colonization and biocontrol efficiency of Trichoderma harzianum. SQR-T037 against Fusarium wilt of cucumbers. Biology and Fertility of
Soils. 47 (3): 239-248.

Zaidi, N.W and Singh, U.S. 2004. Mass multiplication of Trichoderma harzianum on cowdung. Indian Phytopathology. 57(2): 189-192.

\section{How to cite this article:}

Swathi, B., A. K. Patibanda, J. Krishna Prasadji, P. V. Krishnayya and Lal Ahamed, M. 2020. Evaluation of Formulations through Testing the Bioefficacy of Selected Trichoderma Isolate against S. rolfsii. Int.J.Curr.Microbiol.App.Sci. 9(09): 301-309.

doi: https://doi.org/10.20546/ijcmas.2020.909.038 